\title{
ANTES QUE HOUVESSE CLÉRIGOS
}

\author{
José Antônio de C. R. de Souza ${ }^{1}$
}

\begin{abstract}
RESUMO: Neste artigo, inicialmente, discorremos sobre o contexto histórico que suscitou a $1^{\text {a }}$ fase do conflito em torno às relaçôes de poder, entre Bonifácio VIII e Felipe IV de França, e as fundamentaçóes teóricas em que o Papa e o Rei se apoiavam. A seguir, analisamos um dos opúsculos anónimos, escrito em defesa da política do Rei contra parte da clerezia franca, que náo queria ser taxada em seus bens, e contra a bula papal Clericis laicos. Por último, apresentamos a tradução do opúsculo Antequam essent clerici.
\end{abstract}

PALAVRAS-CHAVE: $1^{\text {a }}$ fase da querela entre Bonifácio VIII e Felipe IV. Pressupostos teóricos em que eles se fundamentavam. O conteúdo do opúsculo anônimo Antequam essent clerici.

Com essas palavras, começa um texto anônimo, produzido certamente na corte de Felipe IV, o Belo, (1285-1314), em resposta à bula Clericis laicos², de Bonifácio VIII (1294-1303), promulgada em 25 de fevereiro de 1296.

Antes de procedermos à sua análise, a fim de facilitar a compreensão do mesmo, vamos contextualizá-lo.

Desde 1294, o rei Felipe IV estava em guerra com Eduardo I (12721307) da Inglaterra, por causa de questóes político-econômicas e feudais envolvendo os territórios da Aquitânia ou Guiana, Gasconha e Flandres e outras regiôes sob a suserania da coroa francesa. Por causa dessa guerra, ambos os reis passaram a extorquir dinheiro do clero, violando os cânones 44 e 46 do IV Concílio de Latrão, (1215), que isentava aquele ordo social de pagar qualquer imposto aos ponteados seculares, salvo em circunstâncias especiais e mediante a autorização expressa da Sé Apostólica.

\footnotetext{
${ }^{1}$ Professor Titular concursado e aposentado da Universidade Federal de Goiás e Investigador Integrado ao Instituto de Filosofia/Gabinete de Filosofia Medieval da Faculdade de Letras da Universidade do Porto. Doutor em História Medieval pela USP (1980). Doutor em História da Filosofia e de Cultura Portuguesa Medieval pela Universidade Nova de Lisboa (2001). Publicou e organizou vários livros. Publicou cerca de uma centena de artigos em revistas especializadas no Brasil, Portugal, Espanha, Itália, Argentina e USA.

${ }^{2}$ Ver SOUZA. José A. de C.R. de; BARBOSA. João M. O reino de Deus e o reino dos homens. As relaçôes entre os poderes espiritual e temporal na Baixa Idade Média (da reforma gregoriana a João Quidort). Porto Alegre, EDIPUCRS, 1997, documento 39, p. 179-181.
} 
Sentindo-se espoliados e prejudicados em seu direito, membros do clero franco e inglês passaram a reclamar ao Pontífice, o qual, igualmente ciente de que, sem as rendas que provinham da Francia e da Anglia, o Papado ficaria numa situação delicada, posto que suas despesas correntes e suas obras assistenciais não poderiam ser concretizadas, por isso, naquela data, o Sumo Pontífice decretou a referida bula, endereçada indistintamente à Cristandade, mas de maneira implícita, àqueles dois monarcas em guerra.

Sem meias palavras, o preâmbulo da bula dá o seu tom:

Para a perpétua lembrança do acontecimento. O tempo mostrou-nos que os leigos sempre foram excessivamente hostis para com o clero, e isto comprova-se de modo evidente face ao ocorrido em nossos dias, pois, não contentes com o que lhes diz respeito, desejam obter o que lhes está proibido e extravasam a sua ganância. Tampouco atentam diligentemente em que se lhes proíbe igualmente exercer qualquer poder sobre... as pessoas eclesiásticas e os seus bens. Antes pelo contrário, os leigos impóem pesados tributos aos prelados e às suas igrejas, e ainda ao clero secular e regular, fazendo-os pagar imposto e taxas. Extorquem-lhes consideráveis tributos dos seus proventos e exigem o pagamento da metade, um décimo ou um vigésimo, ou uma outra importância qualquer, além de se empenharem de muitos modos em escravizá-los e pô-los sob o seu domínio... ${ }^{3}$

De um lado, sob pena de incorrerem em excomunhão, a bula proibia aos eclesiásticos darem quaisquer espécies de auxílio financeiro às autoridades seculares, a não ser se fossem expressamente autorizados pelo Papa:

É nosso desejo pôr um fim a tal atos ilícitos. Por isso, tendo ouvido os nossos irmãos, os cardeais, decretamos pela autoridade apostólica, que os prelados e as pessoas eclesiásticas, religiosas ou seculares... que aos leigos pagarem, prometerem ou consentirem em fazê-lo, dízimos, contribuiçōes ou tributos, vigésimos ou centésimos do seu patrimônio pessoal ou das rendas e possessóes das suas igrejas, ou ainda pagarem uma quantia, porção ou quota de seus próprios proventos ou bens... sob a forma de ajuda, empréstimo, subvenção, subsídio ou a modo de presente, ou ainda sob qualquer outro pretexto, modalidade ou solicitaçáo, sem prévia autorização desta mesma Sé Apostólica, incorrerão na sentença de excomunhão... ${ }^{4}$

\footnotetext{
${ }^{3}$ Op. cit., p. $179-180$.

${ }^{4}$ Op. cit., p. 180.
} 
Por outro lado, sob a ameaça de também virem a ser excomungados, a mencionada bula vetava igualmente aos príncipes e aos seus oficiais imporem ao clero e às suas propriedades qualquer tipo de cobrança fiscal:

Igualmente incorrerão em semelhante castigo, os imperadores, reis, príncipes, duques, condes, barōes... e demais autoridades... e qualquer pessoa, de qualquer lugar de origem, estado ou condiçáo social, e aqueles que impuserem, demandarem ou receberem tais bens, incluindo os que se atreverem a violar, tomar ou ocupar as propriedades das igreja ou os bens das pessoas eclesiásticas... e aqueles que souberem de tais fatos e prestarem ajuda, conselho e apoio a tal empreendimento, oculta ou publicamente...

Herdeiro de uma linhagem de papas juristas, entre os quais, Gregório VII (1073-1085), Inocêncio III (1198-1215) e Inocêncio IV (1243-1254), que, juntamente com canonistas e teólogos, formularam e ampliaram as bases teóricas da hierocracia papal, ao assumir a Sé Apostólica, em dezembro de 1294, Bonifácio VIII tinha em mente prosseguir na política de seus mencionados antecessores quanto ao governo da Ecclesia/Christianitas.

De fato, os propositores e defensores ${ }^{6}$ dessa teoria política, ancorada no neoplatonismo, também conhecida por Sacerdotalismo ${ }^{7}$, resumidamente sustentavam que, na condição de vigário de Cristo, o Sumo Pontífice possuía um poder pleníssimo, a plenitudo potestatis, graças à qual tinha o direito de exercer uma suserania, ao menos teórica, sobre todos os fiéis, bem como uma jurisdição ${ }^{8}$ irrestrita nas esferas espiritual e secular, já que tinha a missão transcendente de lhes proporcionar os meios para alcançar a Beatitude ou

\footnotetext{
${ }^{5}$ Op. cit., p. 180.

${ }^{6}$ A forma acabada da mesma, encontramo-la nos escritos de Ptolomeu de Lucca O. P. (Determinatio copendiosa de iurisdictione imperii), Egídio Romano OESA (Sobre o poder eclesiástico), Tiago de Viterbo OESA (De regimine christiano), Agostinho Triunfo OESA (Summa de potestate ecclesistica) e Álvaro Pais O. Min. (Estado e pranto da Igreja), os quais vieram a lume, entre 1300-1347, período esse que assinala a agudização do conflito ente Felipe IV e Bonifácio VIII e, pouco depois, entre Ludovico IV (1314-1347) e João XXII (1316-1334) e seus sucessores imediatos, Bento XII, (1334-1342) e Clemente VI (1342-1352).

${ }^{7}$ PRELOT, Marcel. As doutrinas politicas. Tradução de Natália Couto, v. 1. Lisboa: Presença, 1973, p. 283: "Determinados homens consagrados a Deus pelo sacramento da Ordem exercem sobre os outros homens, um poder o mais eminente que existir possa... transforma-se em «sacerdotalismo» quando se estende ao domínio do poder temporal, recusando conceder a este um valor próprio e conferindo-lhe um carácter ético..."

${ }^{8}$ Entende-se, por esse conceito, as competências para, não apenas julgar as causas encaminhadas à cúria pontifícia, mas também a de legislar sobre quaisquer matérias. Na mesma aceção já está implicitamente incluída a atividade administrativa eclesiástica universal exercida com os cardeais e demais prelados a trabalhar em Roma.
} 
Felicidade eterna, no outro mundo. Por esse motivo, igualmente, tinha o direito de fazer tudo o que achasse pertinente, em ambas as esferas de poder, inclusive no âmbito secular, desde que isso não fosse proibido nem pela lei Divina nem pela lei natural. Por esses motivos, também, ele se achava no direito de julgar religiosa e moralmente a conduta de todos os cristãos, até mesmo dos mais eminentes dignitários seculares.

Dois passos do Novo Testamento, principalmente, fundamentavam essa conceção teológico-política; o primeiro se encontra no Evangelho de Mateus, 16, 16-20, no qual, dirigindose a Pedro e prometendo-lhe, Jesus disse: "Tu és Pedro e sobre esta pedra edificarei a minha Igreja. Dar-te-ei as chaves do reino dos céus e tudo o que ligares na terra será ligado no céu e tudo o que desligares na terra será desligado nos céus e as portas do inferno não prevalecerão contra ela”. Esses versículos se articulam com um outro, do Evangelho de João, 21, 15-17, no qual, após Sua ressurreição, o Filho de Deus confirmou a sobredita promessa, ao confiar a Pedro e, na pessoa dele, aos seus sucessores, os papas, a solicitude pastoral geral dos cristãos e dos pastores deles, ao ter-lhe dito: "[...] apascenta as minhas ovelhas... apascenta os meus cordeiros".

Ademais, segundo os pensadores hierocratas, a superioridade hierárquica e jurisdicional do Romano Pontífice, no que concerne a ambas as esferas de poder, de uma parte, também se fundamentava no Evangelho de Lucas, 22, 38, em cuja passagem, pouco antes de ter sido aprisionado pelos soldados da Sinagoga, no horto das Oliveiras, conversando com seus Apóstolos, Jesus alude à compra de uma espada e, imediatamente, eles Lhe dizem: "Senhor, eis

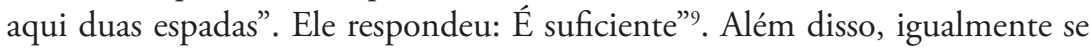
apoiava na narrativa de João, segundo a qual, após Pedro ter desembainhado sua espada e cortado a orelha do soldado do Sumo Sacerdote, Jesus ter-lhe

\footnotetext{
9 Se bem que esses dois gládios representassem simbolicamente os poderes espiritual e temporal, em geral, o gládio espiritual denotava a competência que os ministros eclesiásticos possuem no que concerne a impor penas de natureza espiritual (oraçôes, jejuns, a excomunhão, em casos extremos) aos confitentes, em reparaçáo dos pecados que tinham cometido, enquanto o gládio material significava, também alegoricamente, a competência de os prelados eclesiásticos, mormente o papa, imporem penas de natureza material (a esmola, por exemplo), aos fiéis.
} 
ordenado que a guardasse na bainha ${ }^{10}$, porquanto, ninguém punha em causa que, conforme um passo da Carta de Paulo aos Romanos, 13, 3 e seguintes, se "[o]s que governam metem medo quando se pratica o mal... se... praticares o mal, teme porque não é à toa que trazem a espada: são instrumentos de Deus para fazer justiça e punir quem pratica o mal”, o gládio material denotava simbólica e concretamente o uso da espada pelos príncipes seculares e seus soldados. Estes, para além das suas obrigaçôes rotineiras, na condição de ministri Ecclesiae, também tinham de usá-lo, com a autorização do Sumo Pontífice, no combate aos hereges, aos inimigos da fé, os muçulmanos e em defesa da Igreja, contra seus inimigos, porque de jure os sacerdotes, os bispos e, mormente, o Papa, não podiam se envolver com a efusio sanguinis.

Conquanto não possamos enquadrar São Bernardo (1090-1153), entre os pensadores hierocratas, uma passagem do De consideratione expressa bem o que acabamos de referir:

Porque tentas usurpar de novo o gládio que te ordenaram por na bainha? Mas se alguém nega que esse gládio é teu, parece-me que não presta bem atenção às palavras do Senhor: "Mete o teu gládio na bainha". Portanto, ele também é teu, e deve ser desembainhado, talvez, por indicação tua, mas não pela tua mão. Se o gládio não te pertencesse, então, quando os Apóstolos disseram: "Eis aqui dois gládios", o Senhor não teria respondido: "Bastam", mas "são demais". Ambos os gládios, a saber, o espiritual e o material, pertencem à Igreja. Mas, com certeza, o material deve ser brandido em favor da Igreja, e o espiritual pela própria Igreja. Este pela máo do sacerdote, aquele pela mão do soldado, mas por indicaçáo do sacerdote e por ordem do imperador... ${ }^{11}$

Para mais, os referidos pensadores identificavam a sociedade latina com a Igreja. De fato, o homo naturalis et politicus, mediante Batismo, renascera para a vida sobrenatural, a única que importava e, assim, na nova condição de cristão, se tornou um homo novus ou renatus e, pela graça batismal, se tornou filho adotivo de Deus e, por isso, também era superior aos integrantes das sociedades naturais ou pagãs, cujos membros não gozam desses privilégios.

\footnotetext{
${ }^{10}$ Jo 18, 10: "Então, Simão Pedro, que trazia uma espada, tirou-a, feriu o servo do Sumo Sacerdote, a quem cortou a orelha direita. O nome do servo era Malco. Disse, então, Jesus a Pedro: Embainha a tua espada”.

${ }^{11}$ São Bernardo de Claraval. De consideratione ad Eugenium papam, IV, 3, $\$ 7$, PL 182, 776. A propósito, ver SOUZA, J. A. de C.R. de. Bernardo de Claraval e Bonifácio VIII: nos 850 anos da morte do primeiro e 700 do segundo. Broteria 158, p. 121-131, 2004.
} 
Ora bem, todos os integrantes da sociedade tinham uma finalidade natural que consiste na sua realização como pessoas. De outro lado, os membros da Ecclesia/Christianitas, além de almejarem a finalidade natural, sob a responsabilidade de todos, mas, sobretudo, dos detentores do poder terreno, tinham ainda uma finalidade sobrenatural que, como nos referimos há pouco, consiste em gozar da Felicidade eterna junto de Deus. Logo, em razão do fim, as ações desempenhadas pelos detentores do poder espiritual, pelo fato de visarem a uma meta mais relevante, espiritual e transcendente, eram mais importantes do que as atividades exercidas pelos detentores do poder terreno, cujas tarefas estão circunscritas a uma finalidade imanente, material e secundária. Não bastasse isso, estes últimos, muitas vezes, abusam do seu poder, cometem injustiças, transgredindo as leis, numa palavra, desprezam a religião e a ética. Por outro lado, em geral, ao desempenharem suas incumbências, os dignitários eclesiásticos observam as normas de conduta religiosa e moral. Por todos esses motivos, eles e, principalmente o Papa, gozavam de um status social mais importante do que as autoridades seculares.

De igual modo, tanto para se atingir a sobredita meta quanto a fim de que todos os membros da Ecclesia/Christianitas vivessem em paz, entre si, eles tinham de obedecer às leis regulamentadoras da convivência nesse tipo de comunidade político-social e religiosa, sui generis, prefigurada alegoricamente na antiga sociedade israelita, leis essas estabelecidas pelas autoridades seculares, sob a orientação e supervisão dos Soberanos Pontífices, os quais, com o fluir do tempo, fundamentados na doutrina cristá, passaram a legislar sobre o comportamento sociorreligioso dos seres humanos.

Ainda, de acordo com as ideias de tais pensadores, apoiados no aristotelismo neoplatonizado, a Ecclesia/Christianitas possuía uma organização política perfeita, alicerçada numa hierarquia ordenada entre seus governantes, bem como entre estes e os súditos.

Ora, caso houvesse, pois, muitos dirigentes supremos a governar a Respublica christiana/Ecclesia, sem estarem subordinados entre si, e cada conjunto de líderes possuísse poderes de natureza diferente, seria impossível dirigir os cristãos ordenadamente, a fim de que pudessem alcançar aquela citada Meta derradeira à qual todos aspiravam chegar, porque, de um lado, os prelados se responsabilizariam apenas por sua missáo espiritual e, de outro lado, as autoridades seculares cuidariam somente das questóes terrenas, o que causaria um enorme prejuízo aos fiéis em geral. 
Dado que a Ecclesia/Christianitas ${ }^{12}$ foi fundada por Jesus Cristo, Deus e homem verdadeiro, era impensável que Ele a tivesse organizado de maneira imperfeita, isto é, confiado o poder governativo supremo dessa sociedade a muitas pessoas. Daí, conforme os ensinamentos do próprio Filho de Deus, em João, 19, $11^{13}$, e de Paulo, em Romanos 13, $1^{14}$, todos os poderes que nela existem foram estabelecidos e ordenados por Deus, de maneira que o secular está subordinado ao espiritual.

Se tivesse sido de outro modo, de um lado, haveria o inevitável risco do conflito entre as autoridades, o qual acabaria por causar a destruiçâo dessa sociedade, como Ele próprio o ensina em seu Evangelho e, de outro, provocaria uma dúvida enorme entre os fiéis, quando elas dessem ordens contrárias, uma vez que não saberiam a quem obedecer. Baste, por exemplo, pensar que, transgredindo um Mandamento divino, os reis ou qualquer outro potentado secular poderiam ordenar que todos os seus súditos trabalhassem aos domingos e dias santificados e, assim, para além do desrespeito à autoridade, nessa sociedade imperariam a confusáo e a desordem, as quais acabariam por levá-la à autodestruição.

Portanto, nessa sociedade concebida desse modo por tais pensadores, o poder supremo está nas mãos do Papa, vigário de Jesus Cristo na terra, principal intermediário entre os seres humanos e Deus e pastor de todas as ovelhas e cordeiros; dele deriva parcelarmente para os prelados e dignitários seculares, a quem os institui, ao aprovar alguém e, posteriormente, ungi-lo e consagrá-lo, direta ou indiretamente, de modo que possam vir a exercer uma fração desse poder, respetivamente, ou à frente desta ou daquela diocese ou deste ou daquele reino. ${ }^{15}$

\footnotetext{
${ }^{12}$ Ver CARVALHO. Mário S. de. Da abominação do monstro: Igreja e poder em Álvaro Pais. Revista da Faculdade de Ciências Sociais e Humanas, Lisboa, v. 7, p. 255-284, 1994. Nesse artigo, o autor não só considera esse duplo conceito, articulada ou separadamente, bem como outros mais, de relevância para o assunto em exame.

${ }^{13}$ Ao ser interrogado por Pilatos, num dado momento, Jesus lhe respondeu, dizendo: "Não terias poder algum sobre mim, se não te houvesse sido dado do alto", isto é, que, por intermédio do imperador romano (Tibério, 14-37), que recebera seu poder de Deus, ele tinha sido nomeado governador daquela província.

${ }^{14}$ Escreve o apóstolo dos gentios: “Todo homem se submeta às autoridades constituídas, pois não há autoridade que năo venha de Deus e as que existem foram estabelecidas por Deus”.

${ }^{15}$ Sobre essas ideias relacionadas com a plenitudo potestatis pontifícia, aqui apresentadas de modo resumido, ver ULLMANN, W. Medieval papalism: The Political Theories of the Medieval Canonists. London: Methuen, 1949; ULLMANN, W. The Growth of papal government in the middle ages. London: 1955; WILKS, M. The problem of the sovereignty in the later middle ages: The papal monarchy
} 
O texto infra de Hugo de São Vítor (ca. 1096-1141) fundamenta, ilustra e condensa o que acabamos de expor:

A Santa Igreja é o Corpo de Cristo, vivificada por um só Espírito, unida e santificada por uma só fé. Os cristãos são os membros deste Corpo e todos, embora sejam muitos, constituem um único corpo em virtude de serem animados por uma só fé e um único Espírito.

Do mesmo modo que, no corpo humano, cada membro tem uma função própria e específica...

Esta universalidade de pessoas compreende duas ordens, a dos leigos e a dos clérigos, como se fossem os dois lados de um mesmo corpo. Os leigos, à esquerda, constituem o lado esquerdo do Corpo de Cristo e são os que servem às necessidades da vida presente. Os clérigos... incumbidos da vida espiritual, formam a parte direita do Corpo de Cristo...

Há duas vidas: uma terrena, outra celeste. Uma do corpo, outra do espírito. Uma para que o corpo viva da alma, e a outra para que esta viva de Deus. Ambas procuram bens, por meio dos quais possam subsistir. A vida terrena alimenta-se com as boas coisas do mundo, e a vida espiritual com bons meios espirituais.

$\mathrm{O}$ que é secular pertence à vida terrena e as coisas espirituais relacionam-se com a vida espiritual. Para que em ambas as espécies de vida se respeite a justiça e se produzam coisas úteis, é necessário primeiramente que haja pessoas que, mediante o seu trabalho e entusiasmo, proporcionem os bens indispensáveis à sobrevivência de todos. Em segundo lugar, que haja pessoas que, mediante a autoridade do seu cargo, distribuam tais bens de modo equitativo, para que ninguém se aproveite e abuse do seu irmão, e assim respeitar-se-á a justiça.

Os leigos ocupam-se... pela obtenção dos bens indispensáveis à vida terrena. Eles exercem o poder secular ou terreno. Os clérigos, por sua vez, têm por incumbência distribuir os bens relativos à vida espiritual. Eles possuem o poder espiritual ou divino.

with Augustinus Triumphus and the publicists. Cambridge: Cambridge University Press, 1963; WATT. J. The Theory of papal monarchy in the thirteenth century: The Contribution of the Canonists. London: Burns and Oates, 1965; TIERNEY. B. The Crisis of church and state 1050-1300. PrenticeHall: Englewood Cliffs, 1964; BURNS, J. H. (Ed.) The Cambridge history of medieval political thought. Cambridge: Cambridge University Press, 1988; BLACK, A. El pensamiento politico en Europa 12501450. Cambridge: Cambridge University Press, 1996. 
Num e no outro poder há vários graus e hierarquia de dignidades, mas ambos estáo sob a chefia de uma só cabeça, como se procedessem e se dirigissem para um mesmo princípio. O rei é a cabeça do poder terreno, o Sumo Pontífice do poder espiritual. $\mathrm{O}$ poder régio, voltado para a vida secular, dirige o que é terreno. Ao contrário, sob o governo do Papa estão as coisas necessárias à vida espiritual.

$\mathrm{Na}$ medida em que a vida espiritual é mais digna do que a terrena, e o espírito superior ao corpo, assim também o poder espiritual precede em honra e dignidade o secular. Além disso, o primeiro tem o dever de ensinar e o direito de julgar o segundo, se este não for bom. Todavia, o poder espiritual, estabelecido exclusivamente por Deus, ainda que erre, só poderá vir a ser julgado por Ele mesmo, conforme está escrito, de modo que o poder espiritual pode julgar tudo, mas não deve ser julgado por ninguém.

É notoriamente evidente que o poder espiritual, considerado como uma instituiçáo divina, precede no tempo e em dignidade o outro, pelo fato de o Sacerdócio ter sido primeiramente instituído por Deus e só mais tarde, por ordem celestial, o poder secular foi estabelecido pelo Sacerdócio.

Por esse motivo, agora, na Igreja, a dignidade sacerdotal deve instituir, consagrar e santificar, por meio da sua bênção, o poder secular. Ora, como diz o Apóstolo, aquele que abençoa é maior do que o abençoado... daí... o poder secular, pelo fato de ser abençoado pelo poder espiritual, ser inquestionavelmente inferior ao mesmo... ${ }^{16}$

Entretanto, desde há algum tempo, assessorado e influenciado pelos juristas burgueses Pedro Flotte (ca. metade do século XIII, morto na batalha de Courtrai em 11 de junho de 1302), $1^{\circ}$ chanceler leigo do reino, desde 1295, Enguerrando de Marigny, (ca. 1260 - 30 de abril de 1315), Tesoureiromor do reino, Pedro Dubois (ca. 1255 - ca. 1321), Guilherme de Plaisians e Guilherme de Nogaret (ca. 1260 - março de 1313), especialistas em Direito Romano, ao se inteirar do conteúdo da Clericis Laicos, Felipe IV reagiu firmemente contra ela. Além de não acatar as determinações papais, contidas

${ }^{16}$ SOUZA, J.A. de C.R. de; BARBOSA, J. M. Op. cit., documento 15, p. 90-91. As obras em latim desse autor estão reunidas na Documenta catholica omnia. Disponível em: http://www. documentacatholicaomnia.eu/1815-1875,_migne,_patrologia_latina_03_rerum_conspectus_pro_ auctoribus_ordinatus,_mlt_h.html. 
nessa bula, em 17 de agosto daquele ano, sob hipótese alguma, o Rei proibiu que ouro, prata, em qualquer formato e outros bens saíssem da Francia e, ainda, expulsou do reino os banqueiros italianos que arrecadavam e transferiam o óbolo de São Pedro para Roma. Com essas medidas, os dízimos cobrados pela Câmara Apostólica sobre os benefícios eclesiásticos existentes no reino foram embargados, não obstante os protestos do Sumo Pontífice.

Os referidos juristas e assessores da coroa, para além de sua formação verticalizada em Direito Romano, conquanto não desconhecessem o direito canônico e o feudal-costumeiro, pertenciam à burguesia emergente, e estamos convencidos de que tais fatos exerceram enorme influência tanto em suas atitudes quanto em seus escritos, porque o citado segmento social estava interessado na centralização do poder político nas mãos do soberano, face aos seus interesses econômicos (atividades manufatureiras, comerciais e financeiras), os quais estavam sendo entravados pela nobreza feudal e pelo clero, grandes proprietários de terras.

Um dos caminhos para essa centralização do poder era sobrepor juridicamente os interesses nacionais aos de particulares tomados isoladamente ou em grupo. Noutras palavras, o direito do reino, ancorado no direito romano ou no Ius civile, devia estar acima tanto dos costumes e dos direitos feudais quanto do direito canônico. Esse processo começou com Filipe Augusto (1180-1223), a quem Inocêncio III (1198-1216) reconheceu, de acordo com o que o próprio monarca tinha afirmado, que em seu reino não havia ninguém com autoridade superior à sua ${ }^{17}$. São Luís IX (1226-1270) prosseguiu na obra centralizadora de seu avô e seu neto, como estamos referindo, aprimorou o processo.

Uma outra conduta, adotada com o mencionado propósito, consistiu em os reis francos terem neutralizado o poder fundiário dos grandes vassalos da coroa, fazendo-lhes guerra e, após vencê-los, terem anexado suas terras ao patrimônio real. Felipe Augusto foi um adversário implacável dos reis Plantagenetas (Ricardo Coração de Leão, (1189-99) e João Sem Terra, (1199-1216), os quais herdaram de sua mãe, Leonor (1122-1204), ex-mulher de Luís VII, (1137-80), o ducado da Aquitânia, os condados de Anjou, do Poitou e outros territórios menores, encravados na Francia. Todavia, a "Questão Inglesa”, apesar do tratado de Paris,

${ }_{17}$ SOUZA, J.A. de C.R. de; BARBOSA, J. M. Op. cit., documento 29, decretal Per venerabilem, p. 134 - 135: "Além disso, como o rei Filipe náo reconhece de modo nenhum ter superior no âmbito temporal, sem nisso lesar o direito de outrem, pôde sujeitar-se e [de fato] submeteu-se à nossa jurisdição, quando talvez parecesse a alguém que ele poderia ter legitimado por si próprio, não como pai em relação aos seus filhos, mas na condição de príncipe para com os súditos..." 
(1259), celebrado entre São Luís e Henrique III (1216-1272), mediante o qual a coroa inglesa reconhecia a soberania franca sobre a maior parte dos sobreditos territórios, ainda não tinha sido plenamente resolvida, pois, conforme referimos páginas atrás, sempre que podiam, não aceitando esse fato, de um lado, os reis ingleses recomeçavam a guerra e, de outro, Felipe IV queria se apropriar do restante da malfadada "herança".

Com tal propósito em mente, Felipe II também foi o mentor da não menos atroz cruzada contra os Albigenses ou cátaros que viviam e gozavam de certa liberdade nas cidades da Provença, cruzada essa (1209) comandada por Simão de Montfort e pelo abade de Citeau, Arnaldo Amaury, ou melhor, contra o poderoso conde Raimundo VI de Tolosa, Toulouse (ca. 1156-1222), seus vassalos e seu cunhado Pedro II (1196-1213), rei de Aragão, visando com esse empreendimento a se apropriar daquele condado rico e próspero, sob os aspectos agropecuário, manufatureiro, mercantil e financeiro, e ainda guarnecer as fronteiras do sul do reino contra os aragoneses.

Mas, tenhamos presente, em rápidas pinceladas, o pensamento dos citados juristas. Impressionados com a beleza estrutural do Direito Romano, em função de sua precisão e clareza, no tocante aos conceitos e definiçôes, à sua consequência rigorosamente lógica, aplicável a todos os casos, derivadas dos princípios jurídicos, assim como à sua rígida formalidade, eles absorveram a maneira de pensar jurídica explicitada no Código (529, Corpus Iuris Civilis, organizado em 4 partes, Digesto, Novelas, Institutas e Pandectas), de Justiniano (527-565: "Um Estado, uma lei, uma Igreja”), passando a considerar como racional, justo e bom tudo o que se inspirava no mesmo.

Fundamentados, pois, nessa fonte, bem como na Ética e na Política de Aristóteles, defendiam eles o célebre princípio enunciado no Digesto: quod principi placuit, legis habet vigorem, proclamando que, na Francia, o rei devia ser o princeps no sentido jurídico-político da palavra, isto é, a fonte e a origem de toda lei, e seu tribunal, a instância judiciária suprema e, na qualidade de chefe de Estado, devia dispor de todos os meios apropriados para proteger o bem, o interesse, a honra e a liberdade de todos. Em nome desse tipo de bonum commune, os juristas não admitiam que houvesse limites ao poder do soberano (tal como o Código assegurava a Justiniano), nem no âmbito judiciário, nem no legislativo, muito menos na esfera administrativa, porque, no entender deles, o poder do monarca provinha diretamente de Deus, sem 
a intermediação da Igreja, perante Quem, no dia do Juízo, teria de prestar contas de seus atos ${ }^{18}$.

Todavia, o referido princípio do Digesto tinha sido historicamente aplicado só aos Imperadores e, ainda por essa razão, pretendendo desvincular teórica e juridicamente a Francia de uma sujeição ao Sacro Império Romano Germânico, já que efetivamente o imperador não exercia uma suserania sobre os reis francos, esses juristas recolheram das Siete Partidas (1265), de Afonso X de Castela (1252-1284), um outro postulado: rex in regno suo est imperator, o qual passaram enfaticamente a apregoar e a defender. Tal expressão significava o reconhecimento de uma soberania régia colocada no vértice hierárquico dos poderes existentes no reino, seja o dos nobres em seus feudos, seja o do alto clero secular em suas dioceses, seja o do regular em suas terras, de acordo com uma teoria proposta pelo jurista franco Felipe de Beaumanoir ( $2^{\text {a }}$ metade do século XIII), igualmente, o primeiro a elaborar uma teoria sobre o poder legislativo do rei.

Ademais, esses juristas também se empenharam nos seus escritos, propositadamente anônimos, de modo a não incorrerem na acusação de hereges, de um lado, a restringir a ação dos detentores do poder espiritual exclusivamente à esfera religiosa, isto é, à celebração do culto, ao anúncio da Palavra revelada, à ministração dos sacramentos aos fiéis e às demais atividades religiosas secundárias, o que, entretanto, na prática era impossível, posto que a Igreja era rica, sob o aspecto fundiário, e os bispos nas cidadesdioceses exerciam o poder judiciário, os abades, igualmente, nas circunscriçóes territoriais das abadias. De outro lado, eles também ressaltaram as características essencialmente profanas, terrenas e legais do poder temporal, a fim de que o rei pudesse agir livre e soberanamente como um princeps em seu reino, de acordo, com o que estava escrito, não apenas no Código de Justiniano, mas também nos textos legais do imperador Adriano (117-138) e dos juristas Gaio (ca. 130-ca. 150), Papiniano (ca. 142-212) e Ulpiano (150-223), incorporados ao mencionado Código, os mais lídimos teóricos do absolutismo imperial à época do Baixo Império (193-284) ${ }^{19}$.

${ }^{18}$ VILlOSLADA, R.; LLORCA, B. Historia de la Iglesia Católica. Madrid: BAC, 1963, v. 2, p. 572.

${ }^{19}$ Acerca das ideias relacionadas com o pensamento político e jurídico dos assessores de Felipe IV, aqui explanadas de modo abreviado, ver: RENNA, Th. Aristotle and the French Monarchy. Viator, 9, 1978; GEWIRTH, A. Philosophy and political thought in the fourteenth century. In: UTLEY, F. (Ed.). The Forward movement of the fourteenth century. Columbus: Ohio State University, 1961, p. 125164; COULET, N.; GENET. Jean P. (Eds.). L'Etat moderne: le droit, l'espace et les formes de l'etat. Paris: C.N.R.S, 1991; WECKMANN, L. El pensamiento politico medieval y los orígenes del derecho 
Foi, portanto, nesse contexto que veio a lume o opúsculo sem título que, como se fosse uma bula papal, passou a ser conhecido por suas palavras iniciais, as quais servem de título a este trabalho e que, agora, passamos a analisar.

Tudo indica que terá sido redigido algum tempo depois do decreto de Felipe IV, de 17 agosto de 1296, ao qual nos referimos páginas atrás, e a bula Coram illo fatemur, promulgada por Bonifácio VIII, em 28 de fevereiro de 1297, por meio da qual, face à solicitação dos prelados francos, dada a continuação da aludida guerra entre os dois reis, se pediu ao Papa que autorizasse o clero a pagar impostos, tendo em vista aquela situação de ameaça permanente, pedido esse que foi acolhido por Bonifácio VIII. Ou, talvez, a bula Et si de statu, de 31 de julho de $1297^{20}$, sancionada pelo Romano Pontífice, revogando a Clericis laicos.

\section{II - O TEOR DA FONTE}

O documento em apreço começa com uma afirmação, no mínimo curiosa, pois, conforme seu autor, o reino dos francos teria antecedido ao surgimento do Cristianismo e suas instituiçóes, entre as quais, o Ordo clericalis. Com efeito, onde terá ele colhido esse dado? Infelizmente, ele não o diz.

O fato é que, à luz dos conhecimentos históricos atuais, ainda que recuássemos ao século I de nossa era, a historiografia romana não diz nada a respeito desses germânicos que penetraram no limes imperial à volta do século III e eram conhecidos por duas grandes tribos, a saber, os francos sálios e os francos ripuários que, mais, tarde, se fundiram no povo franco.

As ideias imediatamente subsequentes já não causam estranheza, em que pese o anacronismo, se o leitor tiver presente o que escrevemos antes, isto é, que, no entender dos juristas assessores do monarca, uma das competências mais importantes do rei era legislar, e em proveito do bem do reino, e, neste

internacional. 2. ed. México: Fondo de Cultura Económica, 1993; BURNS, J. H. (Ed.). The Cambridge history of medieval political thought. Cambridge: Cambridge University Press, 1988; TIERNEY, B. The Crisis of church and state 1050-1300. Englewood Cliffs: Prentice-Hall, 1964; BLACK, A. El pensamiento politico en Europa 1250-1450. Cambridge: Cambridge University Press, 1996.

${ }^{20}$ Ver: DYSON, R.W. Three royalistic tracts, 1296-1302: Antequam essent clerici; Disputatio inter Clericum et Militem; Quaestio in utramque partem. Bristol: Thoemmes Press, 1999, Introduction, p. xiii:"The allusion is clearly to Philip's edict of 17 August 1296, issued in response to Clericis laicos, and no doubt partly intended to deprive the papal treasury of its revenues from the French church. This allusion is enough to establish August 1296 as our terminus a quo. For reasons which we shall mention shortly, our terminus ad quem is the appearance of the bull Etsi de statu at the end of July 1297..." 
caso específico, promulgar leis visando à defesa do reino e a coibir toda e qualquer ameaça da parte dos seus inimigos.

Por esse motivo, temendo que armamento, cavalos, moedas de ouro e prata e outros bens preciosos saíssem ocultamente do reino e, de algum modo, fossem parar nas mãos dos ingleses e, de certa forma, beneficiando-os, Felipe IV decretou que os mencionados bens ou riqueza estavam proibidos de deixar a Francia.

Entrementes, diz o autor do documento que o rei abriu uma exceção, ao acrescentar que, se os clérigos comprovassem que tais bens, se levados para fora do reino, efetivamente, não iam causar prejuízos a ambos nem tampouco beneficiar aos inimigos, e ele avaliasse que essas coisas não iam acontecer, ele autorizaria que esses bens saíssem do reino.

A seguir, certamente se recordando da conversão e do batismo de Clóvis e do povo franco e, em vista disso, eles serem considerados os filhos primogénitos e mais queridos da Igreja, porque os outros povos germânicos, tais como os Gôdos e Visigôdos, ao se converterem ao Cristianismo, tinham abraçado a heterodoxia ariana, o autor salienta e justifica que, considerando que a liberdade do reino estava ameaçada e que alguns clérigos não davam a mínima importância para esse grave problema, o monarca náo titubeou, mandou aprisioná-los e se apropriou dos bens deles. Todavia, não é por isso que Bonifácio VIII teria o direito de insinuar que ele corria o risco de vir a ser excomungado, posto que, ao dizer isso, o Papa estava se intrometendo num assunto de interesse do reino, que náo era da conta dele.

Logo adiante, bem à maneira escolástica de argumentar, o autor do pequeno tratado recolhe do Novo Testamento uma série de citaçóes, com o propósito de elaborar o arrazoado de cariz teológico, por meio do qual tenciona justificar e defender as açóes de Felipe IV. (Sem cometer exagero, podemos pensar que o autor do texto seria um clérigo secular, do círculo palaciano, à semelhança de Jean Poully, professor de Teologia na Universidade de Paris). Seu ponto de partida, embora não fosse uma novidade teológica que, entretanto, no dia a dia da vida eclesial, desde o final do século XI, de certo modo foi posta à margem, consiste em asseverar que a Igreja, esposa de Jesus, cujos membros professam uma só crença e recebem apenas um Batismo, a comunitas omnium fidelium, é constituída não exclusivamente pelos clérigos, mas também pelos leigos, porque Jesus tanto os libertou dos grilhóes do pecado, do senhorio de Satanás e dos inúmeros ritos e cerimônias que os judeus tinham de seguir, quanto, sobretudo, tornou-os todos eles filhos adotivos de Deus. 
É certo que Jesus não padeceu e morreu somente pelos clérigos. Ademais, já que Deus não faz distinção entre as pessoas, como ensinam os apóstolos Pedro, Tiago e Paulo, não serão apenas os membros da clerezia que, na outra Vida, irão ser recompensados por Deus, mas, na verdade, todos aqueles que acreditam na Boa Nova e que, por causa dela, fazem o bem.

Além disso, não é por causa do grande número de pessoas que faz parte do Ordo clericorum ou devido às suas questionáveis virtudes que seus membros devam indistintamente gozar da imunidade fiscal, porque é justo que quem tem muito mais do que os outros e quem apregoa a obrigação de se fazer o bem, dê o exemplo e doe uma pequena parcela desse muito, até por se tratar duma causa nobre.

Aliás, é verdade indubitável que, por causa da missão que desempenham, a qual consiste nas várias formas de celebraçôes de louvor a Deus e na instrução dos fiéis que, maxime, deve pautar-se pelo bom exemplo, os eclesiásticos usufruem de um bom número de isençôes fiscais decretadas pelos Sumo Pontífice e que, de bom grado e graças à sua liberalidade, foram confirmadas e concedidas pelos reis e demais autoridades seculares.

Entretanto, conforme o próprio Jesus ordenou aos sacerdotes da religiáo judaica e, na pessoa deles, aos Pontífices da Nova Aliança, dizendo: "Dai a César o que é de César e a Deus o que é de Deus". [Mt 22, 21] e, igualmente, as pessoas de bom senso e os sábios recomendam, essas isençóes fiscais amplas de que goza a clerezia não devem chegar ao ponto de serem nocivas à boa administração, à defesa $\mathrm{e}$ às necessidades do reino.

De seguida, com o mesmo propósito, o autor do opúsculo introduz uma nova prova, a qual é uma mescla de argumento de natureza filosófica e de cariz teológico. Com efeito, de um lado, está implícita ideia de Aristóteles, registrada na Política e explicitada na comparação do corpo com um reino e do rei como o coraçáo do mesmo, aqui, na variante da cabeça, e, de outro lado, enunciada na analogia paulina do Corpo Místico. De fato, como faz falta ao corpo humano e é de lastimar que um membro paralítico esteja impossibilitado de cooperar com ele, assim também é abominável que leigos e clérigos se neguem a auxiliar seu rei e seu reino, num momento delicado pelo qual passa, agindo como se fossem membros inúteis ao corpo social.

Por esse motivo e ainda presente o dado que, de acordo com os cânones, os membros do clero estão proibidos de empunhar armas e guerrear, foi-lhes requisitado, conforme pudessem, uma contribuição que eles, injustamente, 
denominam taxas ou confiscos ou arrestos, destinada a remunerar aquelas pessoas que a administração pública arregimentou para lutar em defesa de toda a sociedade e do rei.

Nesse sentido, porque ninguém tem o dever de lutar pelos outros às próprias expensas e, conforme o direito natural, pouco importa o seu status social, ninguém pode cometer uma injustiça contra o semelhante; se os inimigos do reino o invadirem, as propriedades da clerezia serão as primeiras a serem tomadas ou destruídas, porque, como antes foi referido, os eclesiásticos estão proibidos de empunhar armas e se, face à aludida ameaça, tais propriedades precisam e devem ser protegidas, é justo igualmente que, por essa tarefa árdua, se pague um estipêndio aos seus defensores.

Ademais, se nas Escrituras vemos o próprio Deus nos instruir que temos de considerar como maus aqueles que náo respeitam as normas do direito natural e os costumes e os querem modificar, consoante os seus interesses, causa muita estranheza a qualquer um, que seja capaz de perceber as coisas, ouvir o Papa, vigário do Filho de Deus na terra, se opondo ao que Jesus ordenou, vetar que se pague o imposto ao rei e, sob a ameaça de excomunháo, tenta impedir ao clero de, na proporção de suas condições, ajudá-lo na defesa do reino e deles próprios.

É preciso denunciar que, apesar de o mandamento da Caridade ordenar, das somas vultosas de dinheiro que recebem dos fiéis como esmolas e do risco de seu mau exemplo vir a ser imitado, os eclesiásticos não cuidam zelosamente das necessidades dos indigentes e, contudo, as pessoas relevam os gastos deles com as amásias, com os amigos, com as roupas luxuosas, com os lautos banquetes e outras coisas mundanas.

De fato, a reta razão, a lei natural e as leis divina e humana sempre proíbem os atos ilícitos e aprovam as boas açóes. Em vista disso, qualquer pessoa de bem, no uso da razão, não considera justo nem decente, ainda mais sob a ameaça de uma condenação da parte do Sumo Pontífice, que, conforme suas possibilidades, os eclesiásticos, cujos bens foram consideravelmente ampliados graças à prodigalidade dos monarcas do reino, agora, ante as vicissitudes da guerra, náo queiram ser agradecidos, retribuindo com uma quantia de dinheiro, mediante a qual estariam ajudando Felipe IV a pagar o armamento comprado, a remunerar e a alimentar não só aos que defendem os bens deles, mas, igualmente, à sociedade em geral e ao reino. Quem proíbe que se preste essa ajuda e quem se recusa a dar esse auxílio financeiro não se dá 
conta de que está indiretamente ajudando o inimigo e, por esse motivo, está a cometer os graves crimes de lesa-majestade e de traiçáo ao reino e ao monarca, a quem compete castigar severamente tais delinquentes.

Os quatro últimos parágrafos têm uma outra peculiaridade interessante: o rei Felipe IV passa a falar em lugar do autor anônimo e, à partida, afirma que, como procederam seus antecessores, ele continuará a professar a fé católica, adorando a Deus, venerando a Igreja e os clérigos e agindo com justiça, mas, de modo algum, irá sentir-se intimidado com ameaças que tolham a sua ação como rei, ante a ameaça de seu inimigo.

Na sequência, o rei apresenta os motivos que o levaram a fazer uma guerra justa contra Eduardo I: a) na condição de seu suserano, ele o intimou a comparecer perante sua cúria, a fim de se explicar, em razão das intrigas que articulava contra Felipe, o que ele não fez; b) após ter sido julgado e condenado pelo crime de felonia, o rei da Inglaterra foi punido com a perda das terras que detinha na Francia, como feudo, tendo renunciado às mesmas; c) Depois, ao invés de tentar recuperá-las recorrendo à justiça e à guerra, optou pelos caminhos da fraude e do dolo.

No penúltimo parágrafo, tratando no mesmo pé de igualdade a Adolfo de Nassau (1292-98), imperador romano germânico, a quem designa por rei dos alemães, primeiramente, a fim de resolver o problema de fronteiras entre os dois reinos, Felipe afirma ter-lhe proposto que, de comum acordo, fossem escolhidos quatro árbitros, dois de cada lado, para tratarem disso, cuja decisão viria a ser acatada pelas partes, mas, se eles, por acaso, entrassem em divergência, uma quinta pessoa isenta restabeleceria o consenso entre eles. Todavia, subentende-se que o acordo firmado a propósito, em 30 de julho de 1297, ficou letra morta. Em segundo lugar, Felipe afirma que Adolfo não poderá reclamar nada a respeito do condado da Borgonha, porque este lhe foi conquistado e tomado em represália à declaração de guerra à Francia, sem que houvesse motivos.

Por último, Felipe retorna ao assunto principal do opúsculo, afirmando que, pelos fatos de a Igreja e a clerezia do reino terem sido magnanimamente agraciadas com muitas riquezas, náo só por ele, mas também por seus antepassados, tendo contado sempre com a proteção da coroa, diferentemente do que ocorreu com os eclesiásticos de outros reinos, a fim de que eles não cometam o pecado da ingratidão, é justo que disponibilizem todos os seus bens em proveito do reino, face à ameaça do inimigo e que, nesse momento 
delicado, ao invés de ameaças, agindo como pai bondoso, Bonifácio VIII o apoie, o tranquilize e o console.

\section{III - $\{2\}{ }^{21}$ ANTES QUE HOUVESSE CLÉRIGOS}

Antes que houvesse clérigos, o rei da Francia mantinha a custódia do seu reino, e podia legislar para protegê-lo, bem como a si mesmo contra as insídias e as ameaças de seus inimigos e, por meio dessas leis, podia retirar-lhes todo tipo de recurso com o qual poderiam mais perigosamente atacá-los.

É por essa razão que, mediante um edito geral, aquele que atualmente é nosso rei e senhor proibiu que saíssem do reino cavalos, armas, dinheiro e objetos semelhantes, certamente, para que esses bens, por meio da fraude dos ímpios, não chegassem às mãos dos inimigos, em prejuízo dele próprio e do reino. Todavia, ele simplesmente não proibiu isso, mas acrescentou que tal ato não devia ser feito sem sua autorização específica, com a reta intenção de que, quando lhe fosse evidente como certo que tais bens, pertencentes aos clérigos, se levados para fora do reino, náo causariam nenhum prejuízo a si e ao seu reino, nem beneficiassem os inimigos, não negaria a autorização para tanto, a ninguém que lhe pedisse e que comprovasse tal coisa. Ora, parece assaz espantoso que, recorrendo à força, o querido filho do Papa tenha arrestado não só os clérigos, mas os próprios bens deles, mas, não é por causa disso que o senhor Papa o acuse de que ele incorreu na sentença de excomunhão.

A Santa Mãe Igreja, esposa de Cristo, não só é constituída por clérigos, mas também por leigos. De fato, como atesta a Sagrada Escritura, assim como há um só Senhor, uma só fé e um só batismo $[E f 4,5]$, assim também, desde o primeiro ao último justo, há uma Igreja constituída por todos os que creem em Cristo, casada Ele próprio, o esposo celestial, mediante o anel de fé: uma Igreja que, por Sua própria morte, Ele próprio libertou misericordiosamente da escravidão do pecado, do jugo da Antiga Lei e do senhorio do Antigo Inimigo, [cf., por exemplo, Rm 12, 3s; 1 Cor 10, 16s; 12, 12s; Cl 1, 18s; Gl 3, 23s], e, mediante essa liberdade, quis que todos, tanto leigos quanto clérigos, aos quais deu a graça para se tornarem filhos de Deus [4] [cf. Jo 1, 12], se alegrem, isto é, todos os que acreditam no Seu nome e receberam os sacramentos da fé cristá. Por acaso Cristo morreu e ressuscitou apenas para o clero? De modo algum! Por acaso Deus faz aceção entre as pessoas, de maneira que, neste mundo,

21 Os números entre \{\} indicam a paginação da citada obra de R W. Dyson, cujo texto em destaque utilizamos para esta tradução. 
apenas os clérigos obtêm a graça e, no outro mundo, fruirão da glória? [Cf. Rm 2,11; Ef 6, 9; Cl 3, 25]. De modo algum! Ora, ao contrário, não tendo feito distinção entre todos os fiéis, Ele prometeu a recompensa eterna àqueles que fazem o bem por causa da fé e do amor. E, conforme é evidente, de acordo com o que foi dito, os clérigos não são em merecimento e número mais importantes e, como que excluindo os outros, a não ser, talvez, cometendo um abuso, não podem nem devem se apropriar da isenção eclesiástica, mediante a qual, por Sua graça, Cristo nos libertou [Cf. Gl 5, 1].

De fato, muitas são as isenções específicas, não gerais, da Igreja, esposa de Cristo, que pertencem exclusivamente aos seus ministros, os quais são ou devem ser os responsáveis pela celebração do culto divino e pela edificação do povo, isençóes essas que foram decretadas pelos Pontífices Romanos, que, entretanto, foram concedidas pelos príncipes seculares, graças à sua generosidade, ou ao menos com a permissão deles. Na verdade, essas isençóes concedidas ou permitidas desse modo pelos próprios monarcas não podem prejudicar o governo e a defesa de seus reinos, nem aquelas coisas que são consideradas necessárias e úteis aos mencionados governo e defesa, conforme a reflexão dos bons e o conselho dos prudentes, de acordo com o que o Senhor disse aos pontífices do templo: "Portanto, dai a César o que é de César e a Deus o que é de Deus" [Mt 22, 21].

Ora, assim como é torpe uma parte que não se articula com o seu todo, assim também, como se fosse paralítico, um membro inútil que recusa prestar auxílio ao seu corpo, todos aqueles que, pouco importa se forem clérigos ou leigos, nobres ou plebeus, que recusa a prestar um auxílio à sua cabeça ou ao seu corpo, isto é, ao senhor rei e ao reino, ou melhor, inclusive a si mesmo, comprovam que eles próprios são partes desconexas e membros inúteis, como se fossem paralíticos. Daí, como se fosse uma subvenção, na medida de suas possibilidades, são solicitados auxílios a tais pessoas, não deveriam ser chamados [por elas] de exaçôes, extorçôes ou impostos, mas, antes, de subsídios devidos à cabeça, ao corpo e aos membros, isto é, um soldo destinado a pagar os defensores e combatentes [6] - por aqueles a quem não é lícito ou que não podem lutar por si mesmos. De fato, ninguém tem a obrigação de lutar pelos outros, com seus próprios recursos, e é óbvio que, se a fúria dos inimigos do reino se tornar incontrolável, é sabido que os bens dos clérigos serão completamente destruídos, por isso, muito mais do que os outros, eles precisam ser defendidos contra um ataque inimigo e, por esse motivo, de acordo com o direito natural, é proibido a qualquer um cometer 
injustiça: ao servo e ao livre, ao clérigo e ao leigo, ao nobre e ao plebeu e, assim igualmente, náo opor o escudo da defesa contra uma espada hostil, nem pagar um salário ao defensor. Por acaso, Deus justamente não nos ensina a ver como réprobos aquelas pessoas que se empenham em subverter o direito natural e os antigos costumes e mudá-los de acordo com sua própria vontade? E, qual sábio que compreende tais coisas, não fica assaz espantado ao ouvir que o vigário de Jesus Cristo proíbe que se dê o tributo a César e que, sob a ameaça de um anátema fulminante e contra o ataque da iniquidade da perseguição injusta, proíbe aos clérigos, na medida de suas possibilidades, de estender a mão que ajuda ao senhor rei e ao reino, ou melhor a si mesmos?

Aos referidos clérigos, apesar de serem negligentes com os pobres, permite-se, ou melhor, aceita-se, conquanto seja um exemplo pernicioso que será imitado. que deem presentes aos histrióes e às amantes; que façam gastos supérfluos com roupas, cavalos, amigos, banquetes e com outras pompas mundanas.

$\mathrm{Na}$ verdade, a natureza e a razão e, de igual modo, as leis divina e humana abominam não proibir as coisas ilícitas e impedir as coisas lícitas, ou melhor, necessárias. Com efeito, quem, no uso de suas faculdades mentais, julgaria lícito e honesto, sob a ameaça de um anátema, os clérigos, na medida de suas possibilidades, serem proibidos de ajudar os seus príncipes, cujos bens foram ampliados, aumentados e dilatados, graças à bondade dos mesmos, contra os ataques e as fatalidades das perseguiçóes injustas, pouco importa a forma que seja, por meio de uma doação ou de um empréstimo ou de uma subvenção àqueles que lutam por eles próprios, pelo rei e pelo reino e combatem e resistem aos inimigos, usando armas, fornecendo-lhes alimentos e pagando-lhes salários? $\mathrm{Na}$ verdade, os que proíbem ou os que se recusam a fazer tais coisas, imprudentemente, não consideram que isto náo é senão ajudar os inimigos, incorrer no crime de lesa-majestade e, de certo modo, querer trair o próprio defensor da república, a quem [8] pretendemos mais solertemente abrir os olhos e, Deus o permita, compete punir esse crime.

De fato, como fizeram nossos antepassados, com fé e devoção adoramos a Deus e, aqui na terra, veneramos a Igreja Católica e seus inúmeros ministros. Mas, de modo algum, tememos ameaças inadmissíveis e injustas dos homens, pois, perante Deus, favorecendo Sua clemência, sempre haveremos de proceder com justiça. 
Por acaso, o rei da Inglaterra, nosso homem lígio, tendo sido convocado a comparecer diante de nós, em nosso tribunal, com todo o respeito que é devido à autoridade do seu senhor, não desdenhou atender [à nossa convocação]? Por isso, fundamentado na justiça e, por meio de um julgamento, tivemos de necessariamente anexar às nossas propriedades as terras que ele tinha recebido de nós e, nessa ocasiáo, o mencionado rei da Inglaterra que nos estava unido pelo juramento de fidelidade e pela homenagem, devido às terras que tinha recebido de nós como feudo, abriu mão delas expressamente, entretanto, depois, se rebelando maldosamente contra nós, tentou reavê-las, não tanto pela força das armas, mas, por meio da fraude e, tampouco, pelo caminho da justiça, da razão e do costume plenamente aprovados. Qual rei, qual príncipe não tomaria para si próprio e náo defenderia como se lhe pertencessem as terras feudais abandonadas de tal modo por seu vassalo e confiscadas por tantos motivos? Por causa desse ato, ele náo deve ser censurado por ninguém e tampouco [não] deve ser repreendido.

Quanto ao rei dos alemáes, o que mais podia ou devia ter-lhe sido oferecido que fosse razoável e proveitoso à paz, senão que fossem escolhidas quatro pessoas idôneas, duas de nosso lado e duas favoráveis a ele, as quais se informariam e tratariam das fronteiras do reino e do império e tudo aquilo que ordenassem acerca dessa questão, ambos os reis acatariam perpetuamente; e se, por acaso, as mencionadas quatro pessoas dissentissem entre si, eles poderiam escolher uma quinta que restabeleceria a concórdia entres elas? E se o predito rei dos alemães reclamar algo a respeito do condado da Borgonha, sua queixa não tem nenhum fundamento. De fato, é sabido por todos que, depois da orgulhosa desconfiança e da guerra declarada feita pelo aludido rei contra nós, fomos compelidos a conquistar o predito condado. Com efeito, por causa de sua desconfiança [10], ele ameaçou tomar medidas mais graves contra nós e, talvez, já as teria levado a cabo, se lhe tivesse surgido a ocasião para fazê-las.

Por acaso, desde há muito tempo, nós e os nossos antecessores não prestamos muitos serviços gratuitos e demos muitos bens à nossa santa mãe Igreja, mediante os quais os seus ministros são muito mais abundante e gloriosamente engrandecidos do que noutros reinos? Em vista disso, Deus quer que eles não incorram no pecado da ingratidão, pelo que, na verdade, não podem negar as devidas subvençóes, antes, pelo contrário, devem oferecer tudo aquilo que têm, principalmente, porque veem claramente que, sem haver um motivo razoável, os mencionados reis nos atacam injustamente. Por isso, neste momento, não devemos ser afligidos 
pela Igreja com mais injustiças, mas, antes, na condição de mãe piedosa, por ela devemos ser apoiados, tranquilizados e aliviados eficazmente dos males iminentes.

SOUZA, José Antônio de C. R. de. Before there were clerics. Trans/Form/Açäo, Marília, v. 37, n. 3, p. 87-110, Set./Dez., 2014.

ABSTRACT: We begin by discussing the historical context of the first phase of the power struggle between Boniface VIII and Philip IV of France, and the theoretical foundations upon which the Pope and the King supported their positions. We then consider one of the anonymous opuscula written in defense of the King's policy against the French clergy faction (they did not want to be taxed on their property), and in opposition to the papal bull Clericis laicos. Finally, we present a translation of this opusculum.

KEYWORDS: First phase of quarrel between Boniface VIII and Philip IV. Theoretical assumptions on which they were based. Content of the anonymous opusculum Antequam essent clerici.

\section{REFERÊNCIAS}

\section{FONTE:}

DYSON, R. W. Three royalistic tracts, 1296-1302: Antequam essent clerici; Disputatio inter Clericum et Militem; Quaestio in utramque partem. Bristol: Thoemmes Press, 1999.

\section{Estudos:}

BLACK, A. El pensamiento politico en Europa 1250-1450. Cambridge: Cambridge University Press, 1996.

BURNS, J. H. (Ed.). The Cambridge history of medieval politicalt thought. Cambridge: Cambridge University Press, 1988

CARVALHO, Mário S. de. Da abominação do monstro: Igreja e poder em Álvaro Pais. Revista da Faculdade de Ciências Sociais e Humanas, Lisboa, v. 7, n. 1, p. 255-284, 1994.

COULET, N.; GENET. Jean P. (Eds.). L'Etat moderne: le droit, l'espace et les formes de l'etat. Paris: C.N.R.S, 1991.

GEWIRTH, A. Philosophy and political thought in the fourteenth century. In: UTLEY, F. (Ed.). The Forward movement of the fourteenth century. Columbus: Ohio State University, 1961. 
PRELOT, Marcel. As doutrinas politicas. Tradução de Natália Couto. Lisboa: Presença, 1973. v. 1.

RENNA, Th. Aristotle and the French Monarchy. Viator, v. 9, p. 309-324, 1978.

SOUZA, José A. de C. R. de; BARBOSA. João M. O reino de Deus e o reino dos homens: as relaçóes entre os poderes espiritual e temporal na Baixa Idade Média (da reforma gregoriana a João Quidort). Porto Alegre: EDIPUCRS, 1997.

. Bernardo de Claraval e Bonifácio VIII: nos 850 anos da morte do primeiro e 700 do segundo. Broteria, Lisboa, v. 158, p. 121-131, 2004.

TIERNEY. B. The Crisis of church and state 1050-1300. Englewood Cliffs: Prentice-Hall, 1964.

ULLMANN, W. Medieval Papalism: the political theories of the medieval Canonists. London: Methuen, 1949.

. The Growth of Papal government in the middle ages. London: Methuen, 1955.

VILLOSLADA, R.; LLORCA, B. Historia de la Iglesia Católica. Madrid: BAC, 1963. v. 2.

WATT, J. The Theory of Papal monarchy in the Thirteenth Century:the contribution of the Canonists. London: Burns and Oates, 1965.

WECKMANN, L. El pensamiento politico medieval y los origenes del derecho internacional. 2. ed. México: Fondo de Cultura Económica, 1993.

WILKS, M. The problem of the sovereignty in the later middle ages: the papal monarchy with Augustinus Triumphus and the publicists. Cambridge: Cambridge University Press, 1963.

Recebido em; 06/09/2014

Aceito em: 27/09/2014 
SOUZA, J. A. C. R. 